\title{
Study on Accounting Internal Control in Oilfield Enterprises

\author{
Qingbin Wang
}

Tianjin CNPC electric energy sales co., LTD. Zip code: 300457, China.

\begin{abstract}
. the standardization and refinement development of financial management require enterprises to establish a sound accounting internal control system. At the same time, there are problems and loopholes in the accounting internal control of oilfield enterprises, which will affect the future economic development of enterprises. Therefore, effective improvement measures must be proposed. The elaboration was proposed to the problems of accounting internal control in oilfield enterprises, focusing on the problems of accounting internal control in enterprises and specific improvement measures.
\end{abstract}

Keywords: oilfield enterprises; Financial staff; Accounting internal control.

\section{Overview of Accounting Internal Control in Oilfield Enterprise}

Accounting internal control mainly refers to the internal control activities to ensure the authenticity and reliability of enterprise accounting information and the safety of enterprise assets. For daily operation of enterprises, internal control can greatly improve the quality of accounting information of enterprises, thus improving the overall management efficiency of enterprises. Among them, the internal control of accounting includes a number of control contents, such as the control of the approval system, the incompatible duty separation control, and the control of the physical assets. To a large extent, enterprises can ensure the safety and integrity of their assets by implementing efficient internal control of accounting. Meanwhile, they can effectively avoid the business and financial risks of enterprises, thus improving the economic efficiency and capital efficiency of enterprises.

To strengthen the internal control and management of accounting, oilfield enterprises can improve the reliability and authenticity of accounting information to a certain extent, so as to improve the quality of enterprise assets. At the same time, the smooth implementation of accounting internal control can also ensure the operation of the supervision and restraint mechanism of oilfield enterprises. Moreover, many oilfield enterprises in China have weak accounting internal control, so they should do well in accounting internal control.The main reason for the weakness of accounting internal control in enterprises is the lack of control awareness among managers, which makes the overall internal control and management of enterprises less effective. At the same time, some oilfield enterprises have internal accounting control system, but in essence only in the form. Generally speaking, the current accounting internal control work of oilfield enterprises is not optimistic, and it must be strengthened.

\section{Importance Analysis of Implementing Accounting Internal Control in Oilfield Enterprises}

\subsection{The Implementation of Accounting Internal Control can Strengthen the Risk Control Ability of Oilfield Enterprises.}

The industrial characteristics of oilfield enterprises is very special, and the market environment of which face is also changeful. Therefore, the oilfield enterprises have large operational risks and financial risks in the operation process. At the same time, the accounting internal control work of oilfield enterprises is very difficult to carry out. Specifically, Oilfield enterprises' capital utilization efficiency is relatively low, and the rationality of the setting of financial jobs is relatively poor, etc., all of which are problems of internal control of accounting. In addition, the accounting internal control problem can easily reduce the efficiency of oil field enterprises' capital utilization, thus hindering the efficient development of oil field enterprises to some extent. Therefore, oilfield enterprises must make scientific and reasonable accounting internal control work according to industry characteristics and their own operating characteristics. The implementation of efficient internal control of accounting 
can largely avoid the risk of oilfield enterprises, thus ensuring the efficient development of oilfield enterprises.

\subsection{The Implementation of Accounting Internal Control can Standardize the Management of Enterprises.}

The establishment and implementation of the internal accounting control system in oilfield enterprises can reduce financial irregularities and regulate the post responsibilities of employees, thus improving the overall management efficiency of the enterprise. Oilfield enterprises' sense of responsibility management is relatively weak, and the implementation of accounting internal control can improve the sense of responsibility of enterprise employees, so as to ensure the efficient completion of work. The operating process of oilfield enterprises is not only influenced by the economic environment, but also influenced by culture or politics. Therefore, oilfield enterprises must have a relatively efficient accounting internal control system, which can reduce operational and financial risks of oilfield enterprises and reduce economic decision-making errors of enterprises.

\section{Detailed Analysis of Accounting Internal Control and Management in Oilfield Enterprises}

\subsection{The Financial Work Quality of Oilfield Enterprises is Poor, and the Quality of Accounting Information Needs to be Improved.}

During the process of enterprise operation, the quality of financial work directly determines the quality of accounting information. Nowadays, some oil field enterprises in China do not pay attention to the control of financial basic work, but neglect the construction of financial management work. As a result, there are many defects and loopholes in financial management work. Therefore, ignoring the construction of accounting internal control work in oilfield enterprises will not only hinder the implementation of financial work, but also have a negative impact on the quality of accounting information in enterprises. As managers of oilfield enterprises pay insufficient attention to the internal control of accounting, the financial staff's sense of responsibility is weak, which leads to the poor quality of financial basic work and low efficiency of oilfield enterprises. Therefore, the oilfield enterprise must do well the accounting internal control work.

\subsection{Some Oilfield Enterprises have Low Efficiency in Asset Management, Resulting in Idle Assets or Waste of Assets.}

Some oilfield enterprises pay too much attention to the asset purchase and neglect the asset use, which makes some assets idle or even waste. The management personnel of oilfield enterprises are easy to be affected by the traditional management system, and the asset liquidity of enterprises is poor, which makes the oilfield enterprises unable to form an efficient allocation and reasonable integration management system. Generally speaking, in the current operation and management of oilfield enterprises, there are problems of inefficient use of assets and waste of funds. Meanwhile, the accounting internal control system of oilfield enterprises is not sound, and the quality of accounting internal control needs to be improved.

\subsection{The Internal Control of the Material Procurement of Oilfield Enterprises Needs to be Improved.}

The material purchase of oilfield enterprises is an important work in normal operation and management. Therefore, the internal control of accounting in material procurement needs to be improved and improved. The purchasing department of some oilfield enterprises cannot implement the procurement work according to the actual situation, which makes the unified procurement work efficiency of the purchasing department lower. At the same time, the oilfield enterprise did not use the necessary check and acceptance system in the material purchase, so it could not give play to the supervision function of accounting internal control. Even some oil field enterprises' material 
procurement work is relatively arbitrary, and the over-budget or no-budget situation often occurs, which makes the material procurement work frequently appears problems. In the process of preparing annual budget, many oilfield enterprises do not compile the procurement budget synchronously, which makes the budget change frequently occur in the process of budget implementation. Moreover, the material procurement of oilfield enterprises generally has the problem of irregular accounting treatment, such as: the purchased assets cannot be transferred into fixed assets in time. These problems led to the loss of state assets to some extent.

\section{Specific Measures to Strengthen Accounting Internal Control in Oilfield Enterprises}

Oilfield enterprises can establish scientific and reasonable accounting internal control system according to industry characteristics and operating conditions. At the same time, the actual operability and rationality of the system content should be considered when formulating relevant regulations.

\subsection{Strengthen the Construction of Accounting Internal Control System in Oilfield Enterprises.}

Internal control of accounting mainly includes internal audit, internal check, internal accounting supervision and internal audit. Among them, the internal audit work needs the oilfield enterprise to strengthen the internal evaluation function, which should be able to carry out the effective evaluation and analysis to the internal operation activities of the enterprise, so as to supervise the management personnel to perform the specific status. The internal containment work is mainly to supervise and restrain the personnel's working process, so as to reduce the occurrence of accounting corruption. Specifically, the internal containment work requires two or more staff members to complete the same work, so as to complete the restriction between each other, so as to ensure the asset security of oilfield enterprises and the quality of authentic and reliable accounting information. Internal accounting supervision is mainly to implement supervision and inspection on oilfield enterprises, so as to reduce the occurrence of fraudulent behaviors and to a certain extent to ensure the development of business activities of enterprises. The internal audit work requires the financial staff to carry out the accounting work process in accordance with the standards, and clarify the division of responsibilities of the audit work, so as to do a good job in the audit of accounting related materials.

\subsection{Improve the Budget Management System of Oilfield Enterprises.}

Financial management personnel of oilfield enterprises should pay attention to the budget management and constantly to improve the implementation of the budget, so as to improve the effect of accounting internal control in oilfield enterprises. Establishing feasible budget and implementing strict audit system for departmental and unit budget, so as to improve the rationality of budget expenditure. The management of oilfield enterprises should understand the budget implementation process in time and correct the problems in the budget implementation process in time. The project of oilfield enterprise should establish strict budget management system and implement strict examination and approval system for projects over budget. Not only the implementation of budget management should be done well, but also the implementation results should be rewarded and punished, so as to constantly improve staff's sense of responsibility.

\section{Conclusion}

The quality of accounting internal control must be improved since the work effect of accounting internal control plays an important role in the future business development of enterprises. Meanwhile, oilfield enterprises, as an important state-owned enterprise in China, cannot play their due supervisory and control functions in accounting internal control. Therefore, the management staff of oilfield enterprises must pay attention to the establishment and improvement of accounting internal control related work, and at the same time strengthen the implementation of accounting control work, so as 
to constantly improve the overall management efficiency of enterprises, and give play to the due supervision and control role of accounting internal control.

\section{References}

[1]. Liu Lili. Research on accounting internal control in oilfield enterprises [J]. Science and technology economics guide,2016(03).

[2]. Qin Liyan. Effective countermeasures to strengthen internal control of enterprise accounting [J]. China commerce and trade,2015(09).

[3]. Wang Xiaojuan. Research on financial management and internal control of enterprise accounting [J]. China market,2014(52). 